\title{
Endorse or Not to Endorse: Understanding the Determinants of Newspapers' Likelihood of Making Political Recommendations*
}

\author{
Fernanda Leite Lopez de Leon ${ }^{\dagger}$
}

July 23, 2015

\begin{abstract}
This paper investigates the determinants of newspapers' provision for political opinion. I empirically examine the role of newspapers' political preferences and market competition on newspapers' decision to make endorsements. Regression results suggest that market competition turns newspapers more likely to make endorsements. Results from a simple model show that newspapers' ideology determine their endorsements, making partisan papers more likely to make political recommendations and endorse challengers than non-partisan newspapers.
\end{abstract}

\section{Introduction}

Political endorsements have an important role in American elections. They affect voters' perceptions about candidates (Knight and Chiang 2011; Ladd and Lenz 2009)

${ }^{*}$ I would like to thank Daniel Benjamin, Steve Coate, Ben Ho, Claudio Lucarelli, Jeff Prince and Ariel White for helpful comments.

${ }^{\dagger}$ University of Kent. School of Economics. E-mail: f.de-leon@kent.ac.uk 
and candidates' vote share (Leon 2013). This paper investigates the determinants of newspapers' provision of political endorsements by focusing on two main issues: market structure and newspapers' political preferences. Understanding these relationships is important for policy issues. Historically, public efforts, such as the Newspaper Preservation Act, have been undertaken in response to the decline of newspapers' circulation to ensure diversity (Busterna and Piccard 1993). The Newspaper Preservation Act authorized the formation of joint operating agreements (JOAs) among competing newspapers operating within the same market area to help newspapers reduce their operating costs. While JOAs allowed newspapers to combine business operations (e.g., advertising and circulation), they were required to maintain separate news operations and editorial sections to decide, for example, political endorsements. Despite such efforts, it is likely that newspapers' level of political activism is a response to market incentives, as described below by The Times Magazine (2008):

"At the time when newspapers are trying to ensure their survival by attracting young readers, the idea of endorsements is both counterproductive and an anachronism... in doing so newspapers are undermining the very basis of their business, which is impartiality." The Times Magazine (2008)

More broadly, this paper contributes to a body of work that investigates newspapers' political preferences and how these reflect onto media reports (Puglisi and Snyder 2015, 2011; Larcinese et al. 2011; Knight and Chiang 2011; Di Tella and Franceschelli 2011; Gentzkow and Shapiro 2010; Ansolabehere et al 2006), and how market structure shapes the media (Cage 2013; Gentzkow and Shapiro 2010; Kim 2008; Chiang 2007).

As discussed above, newspapers' political endorsements are relevant in elections and interesting by themselves. More generally, they are a good case study to overcome measurement challenges and to understand the relationship between newspapers' provision of political opinion and market competition. Firstly, endorsements represent a clear stand in favour of a candidate. Secondly, during elections, newspapers face an identical opportunity to take a stand. Therefore, their choice set is observable, as opposed to news 
that is determined by a random occurrence of events and is thus unobservable to readers until reported. Measuring the correlation between competition and a newspaper's reporting practice is also challenging. Newspapers face a different set of competitors in different geographical areas, while news itself is supposed to reach all newspaper readers. Political endorsements are tailored messages for a subset of readers - namely, those who live in a particular political jurisdiction. This feature allows one to test whether and how the level of competition a newspaper faces in an electoral jurisdiction correlates with its behaviour. As I will further develop in Section 3, I expect a relationship between newspapers' political endorsements and market competition. Market structure correlates with newspapers' characteristics, such as ideological positioning (Gentzkow and Shapiro 2010; Chiang 2007) and politicians' behaviour (Snyder and Stromberg 2010). As a result this will determine newspapers' evaluation of candidates and, hence, their endorsements.

To identify the association between market competition and newspapers' likelihood of making endorsements, I collected information on demographics and the newspaper industry's structure at the county level, and transform those to the level of newspaperjurisdiction. I then constructed a variable that is the fraction of the political jurisdiction in which a newspaper operates as a monopolist, and I test how this variable correlates with the likelihood of an endorsement. Variations in the data enabled me to compare endorsement behaviour across areas where newspapers face a different degree of competition, holding constant politicians' behaviour, readership, and newspapers' intrinsic characteristics. Hence, I was able to circumvent and separate confounding effects regarding measurement of the impact of market structures on newspaper behaviour, such as the selection of politicians that run for election in different jurisdictions, or characteristics of newspapers that are established or determine local market structures. This strategy differs from previous studies that explore the entry and exit of newspapers in markets (Cage 3013, Chiang 2007), or those that compare reports of newspapers located in cities with different market structures (Entman 1985), to identify the effects 
of market competition on newspaper behaviour. ${ }^{1}$

I find that market competition does correlate with newspapers' endorsement practices. Several channels contribute differently to this association. Newspapers that circulate in monopolistic areas (and possibly determine local market structure) are inherently more likely to make endorsements. However, an analysis within a newspaper across jurisdictions provides weak evidence that newspapers behave as if they prioritize making endorsements in areas where they face more market competition. The findings of this paper suggest that market competition can make newspapers more active in making political endorsements. These results are relevant in light of the current change in the newspaper industry structure due to the financial crisis and bankruptcy of many city papers (Kirchhoff 2010).

In the second part of this paper, I conduct a different and separate analysis addressing the question of whether and to what extent newspapers' ideological preferences affect endorsement behaviour. Previous studies have used endorsements to identify newspapers' political slants (Kim 2008; Knight and Chiang 2011; Larcinese et al. 2011). This paper provides a novel model that quantifies how newspapers' preferences affect their political endorsements. After estimating these preferences, I conduct counterfactuals to understand newspapers' trade-offs between candidate characteristics and how their political preferences translate to their likelihood of making endorsements. I developed a two-stage model that explains, sequentially, the newspaper's decisions in researching candidates and announcing an endorsement, and then, the choice of whom to endorse. I consider an environment where newspapers are characterized by a political orientation - left-wing, neutral or right-wing — and only make informed endorsements. The newspaper's decisions in researching candidates in a race takes into consideration endorsements costs and the (expected) valuation of candidates' characteristics (i.e.,

\footnotetext{
${ }^{1}$ Cage (2013) finds that more newspapers in a market are associated with fewer news articles and lower information provision. Chiang (2007) finds that newspaper competition reduces the frequency of ideological extreme individuals to obtain political news online. Etman (1985) finds modest effects of competition in terms of diversity of newspapers' content.
} 
incumbency and ideological alignment with the newspaper and its readership in the jurisdiction). The model is estimated using endorsement choices from 90 American newspapers over 154 races in the 2002 and 2006 elections.

The results are consistent with the view that newspapers are politically oriented: they take their political preferences into consideration when choosing their endorsements. This in turn makes partisan papers at least $25 \%$ more likely to declare endorsements than non-partisan papers. The estimated parameters indicate that political alignment between the candidate and the newspaper is a more valuable characteristic to explain the endorsement choice than the political alignment of the candidate with the jurisdiction readership. This finding is more consistent with the supply-led view of media bias, than the demand-driven view. In addition, the estimates detect that left-wing papers (as opposed to right-wing papers) are those that most value their own political alignment with candidates when deciding whom to endorse. One important implication of this asymmetry of preferences is that newspapers' political orientations are predictors for the 'quality' of their endorsed candidates.

This paper proceeds in five sections. Section Two explains the data and the constructed measure of the degree of competition faced by newspapers at the jurisdiction level. Section Three documents the association between the likelihood of endorsements and market competition. Section Four describes the structural model of endorsement, and presents its results. Section Five concludes.

\section{Data}

\subsection{Background and Sources}

Political endorsements are located in the editorial or opinion-editorial section of a newspaper. The editorial section contains the institutional opinion of the newspaper, representing its voice for endorsing candidates, taking a stance on issues, criticizing official decisions, and commenting on events. The editorial board decides what and 
whom the newspaper endorses (Meltzer 2007).

This study explains the political endorsement choices of 90 American daily newspapers in electoral races for the U.S. Senate, the U.S. House of Representatives, State Governor, Secretary of State, State Attorney General, and the State Senate in 2002 and 2006. In total, 154 electoral races were considered. For each newspaper, endorsement choices were observed in up to twenty-five political races. These are listed in the Appendix.The chosen newspapers were from seven states - California, Florida, Michigan, Ohio, Oregon, Texas and Wisconsin - comprised of 658 counties.

The newspaper sample met two criteria. First, the newspapers all report to the Audit Bureau of Circulations (ABC), ${ }^{2}$ hence data about their circulation is available. Most American newspapers do not follow an endorsement practice (Phoenix Discourse 2008). Since this study aimed at identifying newspapers' incentives for making endorsements, the second criteria to be in the sample is that each newspaper made at least one endorsement in any race of the 2002 or 2006 elections. To be more confident that the remaining sample (of non-endorsement papers) did not follow an endorsements practice, I made phone calls to $10 \%$ of them and all confirmed this information. Furthermore, the choice of these seven states was based on the representativeness of newspapers audited by the $\mathrm{ABC}$, which represents around $30 \%$ of the total newspapers within these seven states. In the remaining states, the ABC's sample represents around $20 \%$ of the total newspapers. (Note that representativeness is crucial to this analysis in order to properly identify market structure.)

I collected information on endorsements from Lexis, Newsbank databases, and newspaper websites. The remaining data consists of candidate and newspaper characteristics, cross-sections of readership demographics and political leanings, and measures of newspaper reader share and market competition within a county. Candidate characteristics were collected from the Election Divisions of the Secretaries of State. Census characteristics (such as race, total population, income, and level of urbanization) were collected from the Census Bureau at the county level. These are a proxy for newspaper

\footnotetext{
${ }^{2}$ The ABC is currently known as Alliance for Audited Media (AAM).
} 
readership. (The composition of newspaper readership is not observable at the county level. I assume that county population is representative of the readership composition at this level.)

To identify a county's political leanings, I used the two-party vote share to John Kerry in the 2004 presidential elections, collected from the Election Divisions of the Secretaries of State. Based on this variable, I created another variable to capture the political homogeneity of readers. It is the absolute distance between the 2004 presidential two party vote-share to John Kerry, and 0.5.

\subsection{Measurement of Market Structure}

The utilized measure of market competition is the proportion of a political jurisdiction in which the newspaper circulates as a monopoly. In constructing this variable, I first classified counties as monopolistic or not monopolistic following the methodology utilized in Borenstein and Rose (1994). A county was classified as having a monopolistic structure if a single newspaper had more than $90 \%$ of total circulation among newspapers circulating in the county. A county was classified as not having a monopolistic structure if no single newspaper accounted for more than $90 \%$ of total circulation. To identify these classes, I used information about newspaper county circulation, available from $\mathrm{ABC}{ }^{3}$

The geographical variation of this variable is illustrated for the state of Ohio in Figure 1. It describes monopolistic counties and the circulation of two local newspapers that follow an endorsement practice during elections: The Cincinnati Enquirer and The Plan Dealer. Both newspapers have a higher reader share ${ }^{4}$ in monopolistic counties.

\footnotetext{
${ }^{3}$ For the 658 counties considered, I identified all the operating newspapers and their participation at that level based on 2005 Audit Bureau circulation data. For the seven states in this study, the newspaper market is composed of 231 newspapers. Larger newspapers are over-represented in this sample.

${ }^{4}$ The newspaper county reader share refers to the percentage of a newspaper's readers that live in a county.
} 


\section{Figure1}

It is possible that newspapers' intrinsic characteristics determine their establishment and/or survival in monopolistic counties, explaining the overall market structure. To make more general conclusions about these correlations, I ran a probit regression using, as a dependent variable, an indicator of whether counties are monopolists. Table 1 shows the results. Monopolistic counties are more likely to be politically homogeneous and have higher income per capita. Consistent with Figure 1, monopolistic counties are important locations for newspapers as they have a higher reader share in these counties. As expected, there are less newspapers circulating in monopolistic counties. Newspapers that circulate in monopolistic counties circulate in more geographical areas (in more counties).

Table 1: here

\subsection{Aggregation at the Newspaper- Political Jurisdiction Level}

Endorsement choices are observed at the jurisdiction level. Since newspaper readership characteristics and market competition are only available at the county level, I aggregated those at the political jurisdiction level. I considered races in which the county is a subset of an electoral district.

The aggregation rule is a simple (weighted) average of county characteristics across counties within a jurisdiction. The weights, which are newspaper specific, are the ratio between a newspaper's reader share at the county level and its total reader share at the political jurisdiction level. They were constructed in the following way: a newspaper $j$ circulates in a state $s$, in a jurisdiction $d$, composed of $m$ counties indexed by $u$. Using the information about newspaper county circulation, I calculated the newspa-

per county reader share $\left(R C_{j u}\right)$,jurisdiction reader share $\left(R D_{j d}\right)$ and Weights $s_{j d}$. Next, 
I constructed newspaper-jurisdiction characteristics $\left(X_{j d}\right)$ as described below, using county characteristics $\left(X_{u}\right)$ and Weights.

$$
R D_{j d}=\sum_{u=1}^{m} R C_{j u}, W e i g h t_{j d u}=\frac{R C_{j u}}{R D_{j d}}, X_{j d}=\sum_{u=1}^{m}\left(\text { Weight }_{j d u}\right) X_{u}
$$

This aggregation was performed for all characteristics (readership and market structure), for all newspapers, in every political jurisdiction where a newspaper circulates. In this fashion, I created newspaper-jurisdiction markets and characteristics that I used to estimate relationships in sections 3 and 4 . Note that this simple aggregation rule generates valuable variation from three facts: (i) for the considered races, a jurisdiction is composed of several heterogeneous counties; (ii) different newspapers have different reader share in the counties that make up a jurisdiction, and (iii) different political jurisdictions are composed of different counties. The variable of interest in this study

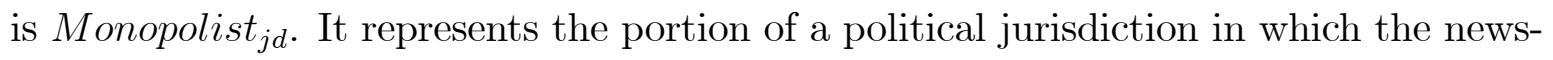
paper operates as a monopolist.

The distribution of this variable is described in Table $2 .{ }^{5}$ On average, $29.02 \%$ of the newspaper readerships live in monopolist areas within a jurisdiction. The standard deviation was 0.389 . An example of the correlation between likelihood of endorsement and market competition was observed for the case of The Cincinnati Enquirer. In 2002, it declared its endorsement for the U.S. House race in district 3 (in which $2.7 \%$ of its readership lived in a monopolistic area). Moving 2.05 standard deviations from this measure was U.S. House District 1 (where $82.5 \%$ of its readership lived in a monopolistic area). For this race, the Cincinnati Enquirer did not make an endorsement.

Table 2: here

Next, I discuss the reasons for some existing relationship between market competi-

\footnotetext{
${ }^{5}$ Recall that I assume that the market is composed only by newspapers in the Audit Bureau of Circulation.
} 
tion and newspapers' likelihood of making endorsements, and then empirically investigate this association.

\section{Market Competition and Newspapers' Likelihood of Making Endorsements}

Market competition may influence newspapers' characteristics and politicians' behaviour. These, in turn, can affect newspapers' evaluation of candidates and endorsement practices. Market structure can affect newspapers' positioning and their political orientations (Andina-Diaz 2007; Gasper 2009; Mullainathan and Shleifer 2005). In a classical study, Mullainathan and Shleifer (2005) develop a model that combines readers that hold beliefs they like to see confirmed and profit maximizing newspapers that can slant stories to cater to readers' beliefs. They show that if newspapers face a readership with heterogeneous views, competition leads to newspapers' polarization with respect to the monopolistic case. Gentzkow and Shapiro (2010) and Chiang (2007) provide tests and find results confirming this hypothesis: under competition, newspapers tend to politically differentiate. Since newspapers' political orientations (probably) determine newspapers' evaluation of candidates, newspapers may have a higher likelihood of making endorsements under competition when they are more likely to be extremely polarized.

Another main channel by which market competition may affect newspapers' decision of making endorsements is by its effects on politicians. Snyder and Stromberg (2010) provide evidence that incumbents attend to their constituencies' needs better in areas where there is greater newspaper coverage. ${ }^{6}$ Market structure might be correlated with media exposure. For example, citizens that live in competitive markets might have characteristics (such as being more educated or politically well-informed) that make

\footnotetext{
${ }^{6}$ They find that politicians who are less covered by the local press are less likely to serve on constituency-oriented committees. Also, federal spending is lower in areas where there is less press coverage of the local members of Congress.
} 
them more prone to read newspapers. In this case, incumbent 'quality' might respond to market structure, turning newspapers more likely to make endorsements.

Next, I report the results of probit regressions explaining a newspaper's probability of making an endorsement. The empirical specification is expressed by (1).

$$
y_{j r t}=\alpha+\gamma \text { Monopolist } \text { jd }_{j}+\delta z_{j d}+\beta_{r} v_{r}+\theta_{j}+\theta_{r}+\theta_{t}+\varepsilon_{j r t}
$$

The dependent variable is a dummy of value one if a newspaper $j$ made an endorsement in race $r$ in year $t$, and zero otherwise. The coefficient of interest is $\gamma$. Other characteristics, possibly correlated with the newspapers' probability of making an endorsement, are controlled for. These are $z_{j d}$, representing newspaper readership (demographics and political views). Electoral race characteristics are represented by $v_{r}$. Newspaper-, electoral race- and year-fixed effects are represented by $\theta_{j}, \theta_{r}, \theta_{t}$, and $\varepsilon_{j r t}$ represents a stochastic error term. Robust standard errors are clustered at the level of the 154 races. $^{7}$

Table 3: here

The results are described in Table 3. Newspapers are more likely to make endorsements in jurisdictions where they operate as a monopoly. This is observed in the raw data (Column 1) and in regressions controlling for readership and electoral race characteristics (Column 2). In Column 3, I include electoral race fixed effects. The size of the correlation between likelihood of endorsement and the monopolist variable is magnified. This suggests a negative impact from candidates that self-select into running for election in monopolistic jurisdictions, in inducing newspapers to make endorsements. The fact that candidates who run for election in races with more market competition

\footnotetext{
${ }^{7}$ Noteworthy, the results become weaker, but largely statistically significant at the $10 \%$ level, when I double cluster at newspaper level and at the race level. They are presented in the Appendix.
} 
are intrinsically more likely to get endorsed suggests a role of market competition in politicians' behaviour.

Column 4 shows the results with the inclusion of newspaper fixed-effects. This specification is useful to circumvent the fact that a newspaper's entry decision in a market correlates with own characteristics (e.g., larger newspapers might be more likely to prevent competition), from the effect of competition on newspaper behaviour across different electoral markets. The distinction between results in column 3 and 4, can be explained by a framework, like the one proposed by Mazzeo (2002), of an endogenous product choice model. He assumes a two-stage model. First, firms with different typeshigh and low types - decide to enter in a market and commit to these entry decisions. Product types are selected simultaneously in a second stage, allowing a high-type firm to profitably offer low-quality services, and behave like a low type. ${ }^{8}$ It is presumably costly to gather political information, and newspapers have a limited amount of resources to allocate to this end. Newspapers that circulate in several electoral markets might allocate these resources to areas where they face more competition as a way to further differentiate themselves. In this specification (column 4), the coefficient $\gamma$ becomes negative and is only statistically significant at the $10 \%$ level.

This reveals two facts. First, the change in the sign of the coefficient $\gamma$ indicates that newspapers that self-select or determine monopolistic markets are inherently more likely to make endorsements. This may be because larger newspapers (as shown in section 2.2 , newspapers that are more likely to circulate in monopolistic counties also circulate in more counties) are more likely to survive as they also have more staff, resources, and the reputation to make political endorsements. This resonates with other findings. Using county-level data on French local newspapers from 1945-2012, Cage (2013) finds that markets with more newspapers are associated with fewer newspaper articles and a lower information provision.

\footnotetext{
${ }^{8}$ Mazzeo (2002) assumes that firms make their product choice (e.g., provide political endorsements) by comparing the payoff to operating under each product type alternative, taking into account that the number of competing firms and their product types will affect the toughness of price competition.
} 
The second result is related to the negative sign of coefficient $\gamma$. It suggests that newspapers also react to market competition as if they are prioritizing in providing political endorsements in areas where they face more competition. This correlation is present regardless of candidates that self-select to run for election in these markets, newspapers' reader share, or newspapers' intrinsic characteristics (such as their ideological views or size).

In the next section, I will present a different and separate analysis to investigate the impact of newspapers' ideological preferences on the likelihood of endorsements. The kind of candidates running for election can influence a newspaper's choice on whether to make an endorsement. Partisan papers might derive more gratification from supporting candidates than non-partisan papers, making them more likely to make political recommendations. In order to quantify this effect, I proposed and estimated a simple structural model that took into consideration the interdependence among endorsement choices (of whether and whom to endorse) and quantified newspapers' political preferences.

\section{A Simple Model of Endorsements}

To illustrate the model's main features and assumptions, consider the environment faced by a hypothetical newspaper that is characterized by a political orientationleft-wing, neutral or right-wing. In a general election, the newspaper faces several simultaneous two-candidate races for which it can make political recommendations. For any election, the newspaper knows some characteristics of the candidates running such as the candidates' incumbencies and party affiliations. These characteristics may affect the newspaper's evaluation of candidates, but the newspaper will not yet be fully informed about other important determinants of its assessment of candidates, such as competence and political record. Thus, the newspaper has to investigate candidates' records and conduct interviews. ${ }^{9}$

\footnotetext{
${ }^{9}$ Meltzer 2007, Post Crescent 2006.
} 
Following newspapers' description of their practice [The Post Crescent (2006)], I assume that endorsements are generated from a two-stage decision during a general election:

- In the first stage, a newspaper decides in which races to make an endorsement. It takes into account the research costs and an "expected" value of endorsing a candidate. The endorsement represents the newspaper's expressive vote: the value of an endorsement is determined solely by the newspaper's evaluation of the endorsed candidate, as opposed to an instrumental model whereby the newspaper seeks to influence the election outcome.

- In the second stage, in the newspaper had decided to research candidates, it becomes fully informed and declares its endorsement.

I next summarize and introduce the notation. A newspaper $j$ has one of three possible political ideological positions $\left(H \in\left\{h_{1}, h_{2}, h_{3}\right\}\right)$, which are left-wing $\left(h_{1}\right)$, neutral $\left(h_{2}\right)$, and right-wing $\left(h_{3}\right)$. In general elections it faces several races $e$, where two candidates $c, c \in\{D, R\}$, are running for election. For any of these, it potentially makes two sequential decisions. First, it makes a decision $\mathrm{t} \in\{0,1\}$ to endorse in a race $(t=1)$ or not $(t=0)$. In making this decision, it compares the cost of investigating an election (and making an endorsement) with the expected value of its announcement. Second, conditional on endorsing in a race, it can make three types of announcements $i \in\{D, R, \varnothing\}$, "endorse the Democrat" $(i=D)$, "endorse the Republican" $(i=R)$, or explicitly declare "no endorsement for either of the candidates" $(i=\varnothing)$. This last announcement represents the newspaper's abstention in a political race once it determines that neither of the candidates meets its standards to receive an endorsement. ${ }^{10}$

From this model, I estimate the following parameters: i) editorial boards' valuations

\footnotetext{
${ }^{10}$ This assumption is based on evidence from the data. When newspapers declare "no endorsement for either candidate," they justify this choice as due to the low qualifications of the candidates. For example, The Record-Eagle made the following announcement in a race, in the 2006 election: "There's no good choice in this race. Incumbent Republican Mike Cox has shown he'll put politics over policy. His challenger, Democrat Amos Williams, isn't qualified."
} 
of candidates' characteristics; ii) newspapers' costs of making endorsements; and iii) a probability distribution for newspapers' political orientations.

I will next detail the payoffs and problems for both decisions, starting with the first. After describing these components and deriving choice probabilities, I explain the estimation procedure.

\subsection{Decision to Endorse in a Race}

In the first decision, the newspaper faces the choice of whether or not to research the candidates characteristics, thus to make an informed endorsement in a race. The payoff of the newspaper's endorsement in a race has two components: its expected benefit and the cost of endorsement. The payoff of the endorsement alternative, denoted by $E N D$, is described below:

$$
E N D_{j}=E\left(Z_{j}^{D}, Z_{j}^{R}\right)-C O S T_{j}\left(R C_{j}\right)
$$

The first element, $E\left(Z_{j}^{D}, Z_{j}^{R}\right)$ denotes the expected benefit of a (future) endorsement. This is the foreseen value of an endorsement and is a function of the ex-ante observable characteristics of candidates running in a political race, as will be detailed in the section 4.2. Under the stochastic term assumptions, this expectation has a wellknown closed form derived in Small and Rosen (1981).

$$
\begin{aligned}
E\left(Z_{j}^{D}, Z_{j}^{R}\right)=E_{\varepsilon} & \max \left\{S^{i^{*}}(H): i \in\{D, R, \varnothing\}\right\} \\
& =\ln \left(\left(\exp \left(Z^{D}\left(C A N_{j}\right)\right)+\exp \left(Z^{R}\left(C A N_{j}\right)\right)+1\right)\right)
\end{aligned}
$$

The endorsement cost, COST conveys both research and reputation costs in making endorsements. I assumed a simple functional form for this, as described below:

$$
C O S T_{j}=\beta_{0}+\beta_{0} \cdot\left(R C E_{j}\right)+\beta_{0} \cdot\left(R C D_{j}\right)+\beta_{0} \cdot\left(R C M_{j}\right)+\zeta_{j}^{C O S T}
$$

It is determined by a fixed endorsement cost common to all newspapers $\left(\beta_{0}\right)$. I then let the cost vary by newspaper size, reader share in a jurisdiction and election characteristics $\left(R C E_{j}\right)$. These characteristics might affect the research cost as they convey, 
respectively, different levels of paper resources and employees, previous political knowledge of the place and politicians' visibility. I allow the cost to vary by readership demographics and political leanings in a district $\left(R C D_{j}\right)$ as these might explain specialization in a market or different perceived costs in making endorsements. ${ }^{11}$ Lastly, the cost might vary by reader share faced in the jurisdiction $\left(R C M_{j}\right)$. The cost variables are compressed in $R C_{j}$, where $R C_{j}=\left(R C E_{j}, R C D_{j}, R C M_{j}\right)$. These are detailed in the Appendix. The cost of endorsement is also determined by a research cost shock $\zeta_{j}^{R E S}$, assumed to be drawn from a type I extreme value distribution. ${ }^{12}$

The payoff of non-endorsing, denoted by $N E N D$, has two components: a deterministic component normalized to zero and a taste shock $\zeta_{j}^{N R E S}$ associated with this alternative. ${ }^{13}$ This is assumed to be drawn from a type I extreme value distribution.

$$
N E N D_{j}=\zeta_{j}^{N R E S}
$$

A newspaper's first decision is whether to make an endorsement $(t(H)=1)$ or abstain from endorsing $(t(H)=0)$ in the race, solving the following problem:

$$
\operatorname{Max}_{t(H) \in\{0,1\}} \quad t(H)[E N D-N E N D]
$$

\footnotetext{
${ }^{11}$ In summary, in this setup, I explain newspapers' candidate evaluation solely on candidate characteristics, based on the idea that the editorial board is looking to endorse the best candidate. On the other hand, I use readership characteristics to explain newspapers' choice regarding which races to provide an endorsement. I based this assumption, that may sound overly simple to some reader, on the classical work of Hamilton (2004, pg. 41). When discussing newspapers' costs in producing and providing news, he describes them as a function of cities' and newspapers' characteristics, and as factors that influenced whether a paper would choose a partisan or non-partisan approach to the news in providing information during the nineteenth century.

${ }^{12}$ This component is unobservable to the researcher and reflects, for example, a shortage of interns to collect information about the politicians, or politicians directly contacting newspapers to facilitate an interview.

${ }^{13}$ This stochastic term is supposed to explain any remaining differences in the endorsement decisions of different newspapers when they face the same research costs. This could be related simply to the editor's mood, for example.
} 
The probabilities of endorsement $(t(H)=1)$ and no endorsement $(t(H)=0)$ are derived based on integration over $\zeta_{j}$ and described below:

$$
\begin{aligned}
& \operatorname{Pr}(t(H)=1)=\frac{\exp \left(E\left(C A N_{j}\right)-C O S T\left(R C_{j}\right)\right)}{1+\exp \left(E\left(C A N_{j}\right)-\operatorname{COST}\left(R C_{j}\right)\right)} \\
& \operatorname{Pr}(t(H)=0)=\frac{1}{1+\exp \left(E\left(C A N_{j}\right)-\operatorname{COST}\left(R C_{j}\right)\right)}
\end{aligned}
$$

\subsection{Decision of Which Candidate to Endorse}

Conditional on having incurred costs in the research process, the newspaper can make two types of announcement. The first type favors a candidate. The payoff derived from this type of announcement is determined by the newspaper's evaluation of the candidate. It has three components: (i) a deterministic component related to the newspaper's political preference; (ii) a deterministic component unrelated to the newspaper's political preference; and (iii) the newspaper's overall evaluation of a candidate's unobservable characteristics - such as quality, honesty and historical record - revealed through research $\left(\varepsilon_{j}^{D}, \varepsilon_{j}^{R}\right)$. These are assumed to be drawn from a type I extreme value distribution. The overall payoff from endorsement of a candidate, denoted by $S_{j}^{c}$, is:

$$
S_{j}^{c}(H, c)=v(H, c)+Z^{c}\left(X C_{j}\right)+\varepsilon_{j}^{c}, \quad c=\{D, R\}
$$

Ceteris paribus, left-wing $\left(h_{1}\right)$ and right-wing $\left(h_{3}\right)$ newspapers give endorsements for Democrat and Republican candidates respectively, as their most preferred decisions. This specific party-candidate preference defines newspapers' partisan status. Neutral newspapers are indifferent between Democrats or Republicans. The payoff $v(H, c)$ that a newspaper of each type derives from its endorsement of a candidate $c$, is as follows:

$$
\begin{gathered}
v\left(h_{1}, c\right)=\left\{\begin{array}{c}
\gamma_{D}, \text { if } c=D \\
0, \text { if } c=R
\end{array}\right\} \\
v\left(h_{2}\right)=0 \\
v\left(h_{3}, c\right)=\left\{\begin{array}{c}
0, \text { if } c=D \\
\gamma_{R}, \text { if } c=R \\
17
\end{array}\right\}
\end{gathered}
$$


The value of $v(H, c)$ when a newspaper makes its less preferred decision is normalized to 0 . The payoff when it makes its preferred decision is $\gamma_{c}$.

The component unrelated to newspaper political preference, $Z^{c}$, is a linear function of two candidate characteristics: if the candidate is an incumbent, represented by an indicator, and whether there is an ideological alignment between the candidate and readers in the political jurisdiction. This last variable assumes value 1 if the candidate is a Democrat (or Republican) and most of a newspaper's readers in the political jurisdiction voted for John Kerry (or George Bush) in the 2004 presidential election. It assumes value -1 if the candidate is a Democrat (or Republican) and most of the readers voted for George Bush (or John Kerry) in the 2004 presidential election.

Besides endorsing the Democrat or Republican, newspapers can explicitly announce "no endorsement for either of the candidates" $(i=\varnothing) \cdot{ }^{14}$ This decision's payoff has two components: (i) a deterministic component that represents the newspaper's standard for making an endorsement where its value is normalized to zero; (ii) newspaper shock specific to this alternative $\varepsilon_{j}^{\varnothing}$, assumed to be drawn from a type I extreme value distribution. ${ }^{15}$ The payoff of this alternative is:

\footnotetext{
${ }^{14} \mathrm{I}$ assume that once the newspaper becomes fully informed, it will always make an endorsement announcement (as is illustrated in Figure A1 in the Appendix). It is possible that some newspapers learn about candidates in some races, but the editorial board does not reach a consensus on whom to endorse and for this reason, they do not make an endorsement (this case is is illustrated in Figure A2 in the Appendix). This could potentially introduce some positive bias on the estimates for the costs of endorsements (as newspapers might be more likely to make endorsements than what is assumed) and the valuation of candidate characteristics might be overestimated (as endorsements made to candidates may occur less frequently than what is assumed among informed newspapers). To check for robustness, I experimented with a one-stage model that relaxed the assumption that newspapers make no endorsement when informed (this is an extreme case of the model in Figure A2) and I find similar qualitative results to the ones reported in the paper. The results are reported in Table A2 in the Appendix.

${ }^{15}$ This component is supposed to capture the unobservable heterogeneity among newspapers within their standards for declaring an endorsement. If newspapers only care about providing helpful advice to their readers, they would just need to pick the 'least worst' among the candidates. However, in some
} 


$$
S_{j}^{\varnothing}(H)=\varepsilon_{j}^{\varnothing}, \quad \text { for any } H
$$

At this (second) stage, the newspaper becomes fully informed and is able to evaluate the respective payoffs of the three alternatives. It decides on its announcement $\mathrm{i}^{\wedge}\{*\}$ according to the rule below:

$$
i^{*}=\arg \max \left\{S^{i}(H): i \in\{D, R, \varnothing\}\right\}
$$

Integrating the shocks, the probabilities of endorsing a Democrat, a Republican, or declaring "no endorsement for either candidate" are respectively:

$$
\begin{aligned}
& \operatorname{Pr}(i(H)=R)=\frac{\exp \left(Z^{R}\left(C A N_{j}\right)\right)}{1+\exp \left(Z^{R}\left(C A N_{j}\right)\right)+\exp \left(Z^{D}\left(C A N_{j}\right)\right)} \\
& \operatorname{Pr}(i(H)=D)=\frac{\exp \left(Z^{D}\left(C A N_{j}\right)\right)}{1+\exp \left(Z^{R}\left(C A N_{j}\right)\right)+\exp \left(Z^{D}\left(C A N_{j}\right)\right)} \\
& \operatorname{Pr}(i(H)=\varnothing)=\frac{1}{1+\exp \left(Z^{R}\left(C A N_{j}\right)\right)+\exp \left(Z^{D}\left(C A N_{j}\right)\right)}
\end{aligned}
$$

\subsection{Log Likelihood Function and Estimation Procedure}

The likelihood of an endorsement observation for a given race $e$ and a given newspaper political orientation type is denoted by $\mathrm{L}_{j e}$ :

$$
L_{j e}(H)=[\operatorname{Pr}(t(H)=0)]^{I(t(H)=0)}+[\operatorname{Pr}(t(H)=1) \operatorname{Pr}(i(H))]^{I(t(H)=1)}
$$

The probability of newspaper orientation type are derived from logit probabilities, explained by a constant particular to each type $\left(\alpha_{1}\right.$ and $\left.\alpha_{2}\right)$, as described below:

$$
\begin{aligned}
& \operatorname{Pr}\left(h_{1}\right)=\frac{\exp \left(\alpha_{1}\right)}{1+\exp \left(\alpha_{1}\right)+\exp \left(\alpha_{2}\right)} \quad \operatorname{Pr}\left(h_{3}\right)=\frac{\exp \left(\alpha_{2}\right)}{1+\exp \left(\alpha_{1}\right)+\exp \left(\alpha_{2}\right)} ; \\
& \operatorname{Pr}\left(h_{2}\right)=\frac{1}{1+\exp \left(\alpha_{1}\right)+\exp \left(\alpha_{2}\right)}
\end{aligned}
$$

Multiple endorsement choices are observed for each newspaper. By combining the sequence of endorsement choices and summing over the possible types of political orientation, the contribution of a newspaper $j$ is $Y_{j}$ :

elections, newspapers might worry about some reputational damage from endorsing a 'bad politician'. 


$$
Y_{j}=\sum_{H \in\left\{h_{1}, h_{2}, h_{3}\right\}} \operatorname{Pr}(H)\left\{\prod_{e} L_{j e}(H)\right\}
$$

The log-likelihood function is then equal to the sum of the log of the individual contributions $Y_{j}$, over all newspapers in the sample: $K=\sum_{j} \ln Y_{j}$. The estimated parameters are the ones that maximize the log-likelihood and are estimated simultaneously. The estimated parameters are: i) editorial boards' valuations of politicians' characteristics; ii) newspapers' costs of making endorsements; and iii) a probability distribution for newspapers' political orientations.

\subsection{Results}

The estimates for the parameters related to newspapers' decisions regarding whether to make endorsements (from equation 3) are described in Table 4. These are the determinants for newspapers' endorsement costs. Because the parameters were measured in a utility metric, I will focus the interpretation on their sign. Newspapers face lower (or higher) costs in jurisdictions where they are more (or less) likely to make endorsements.

The results point to the positive cost of making endorsements, as revealed by the sign of $\beta_{0}$ (7.462). Newspapers face different costs according to the election, readership, and newspaper characteristics. The cost becomes lower as the share of a newspaper's readers who live in the political jurisdiction increases. This is consistent with the expectation that newspapers hold more political knowledge and face lower research costs in these elections. Larger newspapers (those among the 100 largest newspapers in the U.S.) face lower costs, and therefore are more likely to make endorsements, compared to other newspapers.

The cost depends on readership race and degree of political homogeneity. Newspapers are more likely (face lower cost) to make endorsements in jurisdictions where there is a higher concentration of whites, blacks, or Hispanics, or where their readership is more politically homogeneous. 
Table 4: here

The estimates for those parameters related to candidates' choice (from equation 4) are described in Table 5. They show that incumbency and ideology are characteristics positively evaluated by newspapers. Both candidate ideological alignment with newspaper's readership and candidate ideological alignment with the newspaper itself explain the endorsement. However, the estimated parameters indicate that newspapers value their own ideological preferences more than those of their readers when deciding whom to endorse.

The coefficients $\gamma_{R}$ and $\gamma_{D}$ (in equations 5 and 6) point to an asymmetry between left-wing and right-wing papers on their valuation of candidates. They suggest that leftwing newspapers value party alignment more than right-wing newspapers when making their decision of whom to endorse. This difference is statistically significant at the $5 \%$ level. This finding is new and has direct implications on the endorsements provided by newspapers with different political orientations; on average, right-wing newspapers should endorse 'higher-quality' candidates.

The model also predicts that newspapers are more likely to be partisan (have a left-wing or a right-wing orientation) than non-partisan (which have a neutral orientation), as described in Table $6 .{ }^{16}$ These results are consistent with the general view of newspapers as politically biased (Pew Research Centre 2005).

Table 5: here

Table 6: here

\footnotetext{
${ }^{16}$ The probabilities are derived from estimated parameters $\alpha_{1}$ and $\alpha_{2}$ and the error distribution assumptions. 
A nice feature of the econometric model is that one can conduct counterfactuals with the estimated parameters of the model. Table 7 presents the estimated probabilities of endorsements when newspapers' political ideologies are exogenously changed. In the model, I assumed that partisan newspapers have an extra incentive to make endorsements in comparison to non-partisan papers, insofar as they are supporting candidates with similar political views. ${ }^{17}$

A direct implication is that this makes partisan newspapers more likely to incur costs when making endorsements than non-partisan papers. According to the results, partisan papers are at least $25 \%$ more likely to make endorsements than non-partisan papers (Row 1). Consistent with the estimated parameters, left-wing (or right-wing) papers are more likely to endorse Democrats (or Republicans) than neutral or right-wing (or left-wing) papers. The implication of these last facts is that most newspapers' political endorsements are 'politically biased' in the sense that they are partially determined by the newspapers' political preferences.

Rows 4-7 provide figures about newspapers' trade-offs between incumbency and ideology when deciding whom to endorse. Incumbency is the main determinant of newspapers' endorsements (Ansolabehere et al. 2006.) It reflects many candidates' attributes, such as experience, 'quality' and any greater likelihood to win the election. As shown in Table 7, all types of newspapers were more likely to endorse incumbents than challengers. However, while non-partisan papers endorsed incumbents at least eight times more often than challengers, partisan papers endorsed incumbents no more than three times more often than they endorsed challengers who shared their political views.

\footnotetext{
${ }^{17}$ Data shows that this is a reasonable assumption. The model assumes newspapers make two sequential choices. However, one can also imagine that newspapers make endorsements without a research process, using only the information they have at hand. In this case, the newspaper's endorsement decision could be modelled by a logit model. I compared this model's predictions with those of a logit with the same number of control variables. The model achieved a higher log-likelihood value (-813.80) than the logit (-855.18), and predicted newspapers' actual choices with higher success than a logit achieved in $57.4 \%$ of the cases.
} 
Table 7: here

\section{Conclusion}

This paper's aim is to contribute to the discussion on newspapers' political behaviour by investigating the determinants of newspapers' political endorsements. It explored the variation of endorsements across races and jurisdictions to uncover two main relationships: (i) the association between the likelihood of endorsements and market competition and (ii) the association between endorsement decisions and newspapers' political ideologies.

The results show that newspapers' likelihood of making endorsements correlates with market competition, suggesting that market competition makes newspapers more likely to make endorsements. This relationship survives regression analysis with the inclusion of newspapers' fixed effects and jurisdiction reader share. To the best of my knowledge, this correlation is new. It has implications on how policymakers should think about the relationship between competition and newspapers' partisan behaviour, including making endorsements.

In the second part of the paper, I provided a simple model for newspapers' political endorsements. Advancing from previous studies, the proposed model endogenizes newspapers' decisions to make any endorsements. It also quantifies to what extent partisan papers are more likely to make endorsements than other papers. The results show that the size of newspapers' preferences for endorsing a party candidate is large, similar to their preference for endorsing an incumbent. This suggests a possible motivation for newspapers to make endorsements: a potential desire to influence election outcomes and to help elect their favourite candidates. This mechanism has not been covered in this study and has been given little attention in the literature. This awaits future research. 


\section{References}

[1] Andina-Díaz, A. (2007). Reinforcement vs. change: The political influence of the media.Public Choice, 131 (1): 65-81.

[2] Ansolabehere, S., Lessem, R., \& Snyder, J. M. Jr. (2006). The orientation of newspaper endorsements in U.S. elections. Quarterly Journal of Political Science, 1(4): 393-404.

[3] Black, E. R. (1982). Politics and the News.

[4] Borenstein, S., \& Rose, N. (1994). Competition and Price Dispersion in the U.S. Airline Industry.Journal of Political Economy, 102 (4): 653-683.

[5] Busterna, J. C., \& Picard, R. G. (1993). Joint Operating Agreements: The Newspaper Preservation Act and its Application. Ablex Publishing Corporation.

[6] Cage, J (2013). Media Competition, Information Provision and Political Participation. Working Paper, Harvard University.

[7] Chiang, C-F. (2007). Political Differentiation in Newspaper Markets.Working paper, Brown University.

[8] Di Tella, R., \& Franceschelli, I. (2011). Government Advertisement and Media Coverage of Corruption Scandals.American Economic Journal: Applied Economics, 3(4).

[9] Entman, R. M. (1985). Newspaper Competition and First Amendment Ideals: Does Monopoly Matter?.Journal of Communication, 35(3), 147-165.

[10] Gasper, J. T. (2009). Reporting for sale: the market for news coverage.Public Choice, 141, (3): 493-508.

[11] Gentzkow, M., \& Shapiro, J. (2010). What Drives Media Slant? Evidence from U.S. Newspapers.Econometrica, 78 (1): 35-71.

[12] Groseclose, T., \& Milyo, J. (2005). A Measure of Media Bias.Quarterly Journal of Economics, 120(4): 1191-1237. 
[13] Hamilton, J. T. (2004). All the News That's Fit to Sell: How the Market Transforms Information into News. Princeton University Press.

[14] Kim, C. (2008). Group Ownership and Newspaper Endorsements.Working paper, Brown University.

[15] Kirchhoff, S. 2010. The Newspaper Industry in Transition.Congressional Research Service Report.

[16] Knight, B., \& Chiang, C. (2011). Media Bias and Influence: Evidence from Newspaper Endorsements. Review Economic Studies 78(3): 795-820.

[17] Larcinese, V, Puglisi, R. and J Snyder. (2011). Partisan Bias in Economic News: Evidence on the Agenda Setting Behavior of US Newspapers. Journal of Public Economics, 95 (9-10): 1178-1189.

[18] Ladd, J., \& Lenz, G. (2009). Exploiting a Rare Shift in Communication Flows to Document Media Effects: the 1997 British Election.American Journal of Political Science 53(1) :394-410.

[19] Leon, Fernanda L L de. (2013). The Tuesday Advantage of Politicians Endorsed by American Newspapers. The B.E. Journal of Economic Analysis \& Policy, 13(2): $865-886$.

[20] Mazzeo, M. (2002). Product choice and oligopoly market structure. RAND Journal of Economics, 33(2): 1-22.

[21] Meltzer, K. (2007). Newspaper editorial boards and the practice of endorsing candidates for political office in the United States.Journalism, 8 (1): 83-103.

[22] Mullainathan, S., \& Shleifer, A. (2005). The Market for News.American Economic Review, 95(4):1031-1053.

[23] Pew Research Center (2005). Trends: 2005.

[24] Phoenix Discourse. (2008). No Endorsement Needed. October, 28.

[25] The Post-Crescent. (2006). What endorsements are about. November, 5. 
[26] Puglisi, R. \& Snyder, J. M. (2015). The Balanced US Press. Journal of the European Economic Association, 13: 240-264.

[27] Puglisi, R. \& J Snyder. (2011). Newspaper Coverage of Political Scandals. Journal of Politics, 73(3): 931-950.

[28] Small, K., \& Rosen, H. (1981). Applied welfare economics of discrete choice models. Econometrica, 49: 105-130.

[29] Snyder, J. Jr., \& Stromberg, D. (2010). Press Coverage and Political Accountability. Journal of Political Economy, 118(2): 355-408.

[30] Times Magazine. 2008. Should Newspapers Still be Taking Sides?. February 2008. 
INDIANA
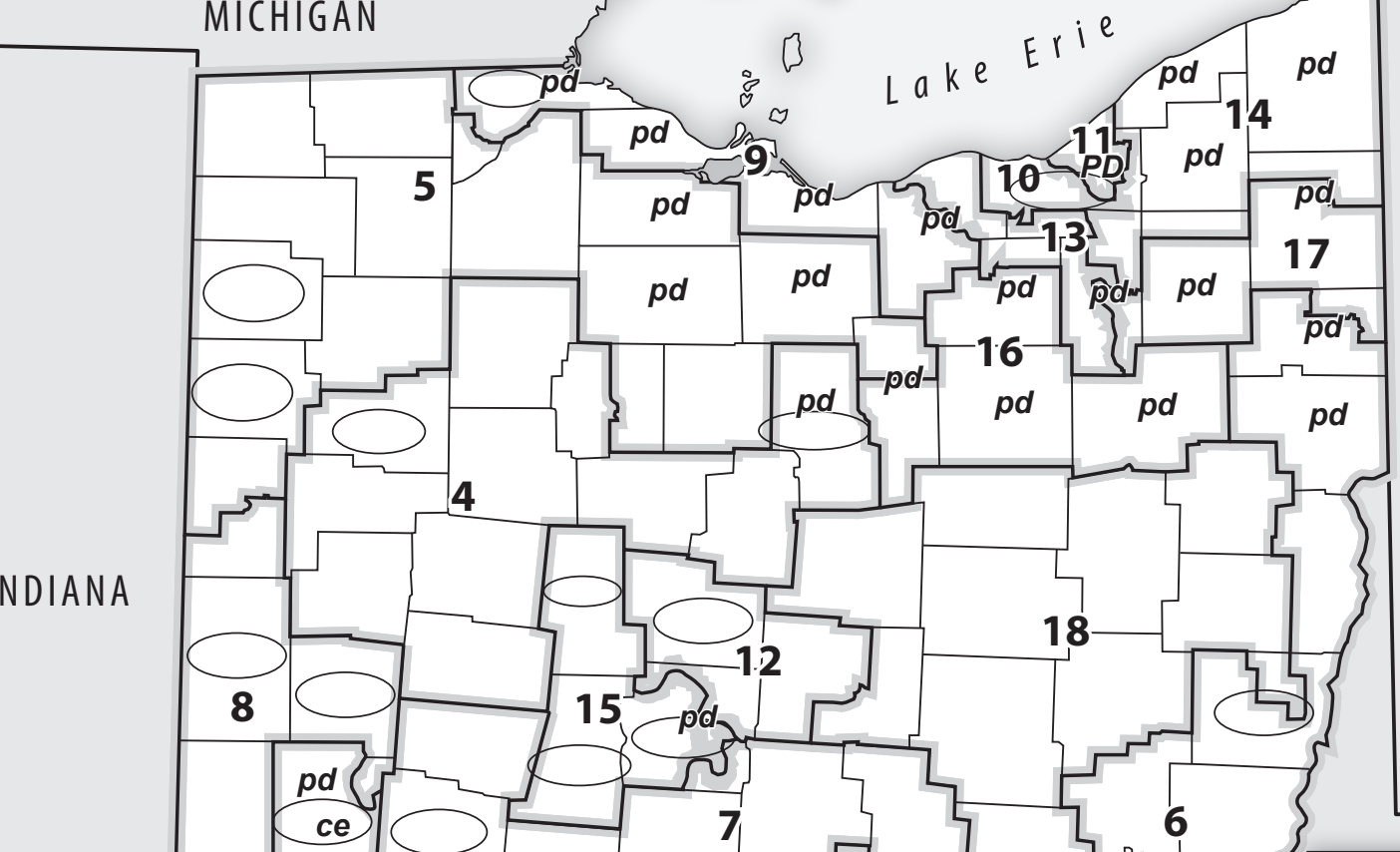

\section{KENTUCKY}

WEST VIRGINIA
Congressional districts are numbered $\bigcirc$ Monopolistic Counties circled

CE Counties where Cincinnati Enquirer reader share is larger than $10 \%$

ce Counties where Cincinnati Enquirer reader share is between $0.1-10 \%$

PD Counties where Plain Dealer reader share is larger than 10\%

pd Counties where Plain Dealer reader share is between $0.1-10 \%$ 
Table 3 - Probability of Newspaper Endorsement in a Race - Probit Results

\begin{tabular}{lcccc}
\hline & {$[1]$} & {$[2]$} & {$[3]$} & {$[4]$} \\
\hline \hline Monopolistic & 0.3331339 & 0.2843569 & 0.5133 & -0.820138 \\
& {$[0.1177]^{* *}$} & {$[0.1316]^{* *}$} & {$[0.2122]^{* *}$} & {$[0.4935]^{*}$} \\
Monopolistic & & & & \\
& 0.3331339 & 0.2843569 & 0.5133758 & -0.820138 \\
& {$[0.1789]^{*}$} & {$[0.1839]$} & {$[0.2646]^{*}$} & {$[0.5776]$}
\end{tabular}

Controls

Reader-share

readership and electoral characteristics

year- and state-fixed effects $(\mathrm{s}=8)$

year- and race-fixed effects $(\mathrm{d}=154)$

newspaper fixed effect $(\mathrm{j}=90)$

\begin{tabular}{llll}
$\mathrm{y}$ & $\mathrm{y}$ & $\mathrm{y}$ & $\mathrm{y}$ \\
$\mathrm{n}$ & $\mathrm{y}$ & $\mathrm{y}$ & $\mathrm{y}$ \\
$\mathrm{y}$ & $\mathrm{y}$ & $\mathrm{n}$ & $\mathrm{n}$ \\
$\mathrm{n}$ & $\mathrm{n}$ & $\mathrm{y}$ & $\mathrm{y}$ \\
$\mathrm{n}$ & $\mathrm{n}$ & $\mathrm{n}$ & $\mathrm{y}$ \\
\hline
\end{tabular}

Notes:

1) Standard errors clustered at the jurisdiction level are reported in brackets

2) Readership controls include income, population, urban, race, two party vote share to John Kerry, political homogeneity index and a dummy indicating whether the newspaper circulates in a jurisdiction. Electoral race controls include indicators for whether the race is statewide and whether there is an incumbent running for re-election in the race.

3) ** Significant at the $5 \%$ level,* Significant at the $10 \%$ level 


\begin{tabular}{lccc}
\hline & Left-wing & Neutral & Right-wing \\
\hline \hline & & & \\
[1] Any endorsement & 32.1 & 24.1 & 30.2 \\
& & & \\
$\quad$ Conditional probabilities & & & \\
[2] Endorsement to a Democrat & 67.8 & 32.1 & 18.8 \\
[3] Endorsement to a Republican & 25.5 & 50.8 & 75.5 \\
& & & \\
[4] Endorsement to a Republican Incumbent ( a ) & 54.9 & 81.2 & 84.0 \\
[5] Endorsement to a Democrat Challenger ( b ) & 39.3 & 9.6 & 3.3 \\
(a)/(b) & 1.40 & 8.47 & 25.69 \\
& & & \\
[6] Endorsement to a Democrat Incumbent ( c ) & 96.8 & 81.6 & 67.6 \\
[7] Endorsement to a Republican Challenger ( d ) & 1.7 & 9.3 & 25.1 \\
(c )/ (d) & 58.30 & 8.82 & 2.69 \\
\hline
\end{tabular}

Notes: 1) conditional probabilities are calculated conditional on endorsements.

2) conditional probabilities do not sum one because newspapers still can declare "no endorsement to either candidate". 
APPENDIX 
Table A1 - Probability of Newspaper Endorsement in a Race - Probit Results

\begin{tabular}{|c|c|c|c|c|}
\hline & {$[1]$} & [2] & [3] & [4] \\
\hline $\begin{array}{l}\text { Monopolistic } \\
\text { (stand error clustered at the newspaper and jurisdiction level) }\end{array}$ & $\begin{array}{c}0.3331 \\
{[0.1789]^{*}} \\
\{0.063\}\end{array}$ & $\begin{array}{c}0.2844 \\
{[0.1839]} \\
\{0.122\}\end{array}$ & $\begin{array}{c}0.5134 \\
{[0.2646]^{*}} \\
\{0.052\}\end{array}$ & $\begin{array}{c}-0.8201 \\
{[0.5776]} \\
\{0.156\}\end{array}$ \\
\hline $\begin{array}{l}\text { Monopolistic } \\
\text { (stand error clustered at the jurisdiction level) }\end{array}$ & $\begin{array}{c}0.3331 \\
{[0.1177]^{* *}} \\
\{0.005\}\end{array}$ & $\begin{array}{c}0.2844 \\
{[0.1316]^{* *}} \\
\{0.031\}\end{array}$ & $\begin{array}{c}0.5133 \\
{[0.2122]^{* *}} \\
\{0.016\}\end{array}$ & $\begin{array}{c}-0.8201 \\
{[0.4935]^{*}} \\
\{0.097\}\end{array}$ \\
\hline \multicolumn{5}{|l|}{ Controls } \\
\hline Reader-share & $\mathrm{y}$ & $\mathrm{y}$ & $\mathrm{y}$ & $\mathrm{y}$ \\
\hline readership and electoral characteristics & $\mathrm{n}$ & $\mathrm{y}$ & $\mathrm{y}$ & $\mathrm{y}$ \\
\hline year- and state-fixed effects $(s=8)$ & $\mathrm{y}$ & $\mathrm{y}$ & $\mathrm{n}$ & $\mathrm{n}$ \\
\hline year- and race-fixed effects $(\mathrm{d}=154)$ & $\mathrm{n}$ & $\mathrm{n}$ & $\mathrm{y}$ & $\mathrm{y}$ \\
\hline newspaper fixed effect $(\mathrm{j}=90)$ & $\mathrm{n}$ & $\mathrm{n}$ & $\mathrm{n}$ & $\mathrm{y}$ \\
\hline
\end{tabular}

\section{Notes:}

1) Standard errors clustered in brackets and p-values in parenthesis.

2) Readership controls include income, population, urban, race, two party vote share to John Kerry, political homogeneity index and a dummy indicating whether the newspaper circulates in a jurisdiction. Electoral race controls include indicators for whether the race is statewide and whether there is an incumbent running for re-election in the race.

3 )** Significant at the $5 \%$ level, $*$ Significant at the $10 \%$ level 
Table A2 - Determinants of Newspapers' Political Endorsements

\begin{tabular}{|c|c|c|c|c|c|c|c|}
\hline & \multicolumn{2}{|c|}{ One stage model } & \multicolumn{5}{|c|}{ Two-stage model (results in the paper) } \\
\hline & coefficient & standard error & & coefficient & standard error & & \\
\hline cost (Benefit of not making an endorsement) & 10.0198 & 0.805 & ** & 7.4615 & 0.3174 & 23.50819 & *** \\
\hline cost $\mathrm{X}$ statewide race & -0.0793 & 0.3086 & & 0.0618 & 0.3007 & 0.20552 & \\
\hline cost $\mathrm{X}$ open race & -0.8865 & 0.2523 & ** & -0.8929 & 0.2499 & -3.57303 & ** \\
\hline cost $\mathrm{X}$ urban areas & -0.2986 & 0.292 & & -0.0771 & 0.2772 & -0.27814 & \\
\hline cost $\mathrm{X}$ population & 0.5931 & 0.3185 & $*$ & 0.6327 & 0.3073 & 2.0589 & ** \\
\hline cost $X$ income & -0.9705 & 0.2092 & ** & -0.9085 & 0.207 & -4.38889 & ** \\
\hline cost $\mathrm{x}$ white & -0.5431 & 0.3063 & $*$ & -1.3849 & 0.2203 & -6.28643 & ** \\
\hline cost $\mathrm{x}$ black & -1.1041 & 0.2223 & ** & -0.8593 & 0.2148 & -4.00047 & ** \\
\hline cost $\mathrm{x}$ hispanic & -1.0919 & 0.2686 & ** & -0.5763 & 0.2464 & -2.33888 & ** \\
\hline cost $\mathrm{x}$ male & 0.0437 & 0.2143 & & 0.0757 & 0.2096 & 0.361164 & \\
\hline cost $x$ political homogeneity index & -3.1918 & 0.8347 & $*$ & -0.6478 & 0.1836 & -3.52832 & ** \\
\hline cost $\mathrm{x}$ newspaper reader-share & -3.8805 & 0.3662 & $* *$ & -3.8624 & 0.3603 & -10.72 & $* *$ \\
\hline cost $\mathrm{x}$ Top 100 newspaper & -0.9895 & 0.2235 & $* *$ & -0.9491 & 0.2222 & -4.27138 & ** \\
\hline cost $x 2002$ Election & -0.5483 & 0.1972 & $* *$ & -0.4701 & 0.1938 & -2.4257 & ** \\
\hline \multicolumn{8}{|l|}{ Valuation of candidate characteristics } \\
\hline Incumbent & 2.0667 & 0.1684 & ** & 2.0662 & 0.1663 & 12.42453 & ** \\
\hline Political Alignment of candidate and readership & 0.3783 & 0.0978 & ** & 0.3646 & 0.097 & 3.758763 & ** \\
\hline Political Alignment of candidate and RIGHT-Wing newspaper & 1.361 & 0.2289 & ** & 1.323 & 0.224 & 5.90625 & ** \\
\hline Political Alignment of candidate and Left-Wing newspaper & 1.9004 & 0.2308 & $* *$ & 1.9461 & 0.2275 & 8.554286 & $* *$ \\
\hline Right-wing type parameter & -0.3437 & 0.4403 & & -0.2545 & 0.4331 & -0.58762 & \\
\hline Left-wing type parameter & -0.2954 & 0.5205 & & -0.243 & 0.5163 & -0.47066 & \\
\hline \multicolumn{8}{|l|}{ Implicit probability of Types } \\
\hline Right-wing & $28.9 \%$ & & & $30.3 \%$ & & & \\
\hline Left-wing & $30.3 \%$ & & & $30.6 \%$ & & & \\
\hline Neutral & $40.8 \%$ & & & $39.1 \%$ & & & \\
\hline
\end{tabular}

** Significant at the $5 \%$ level,* Significant at the $10 \%$ level 

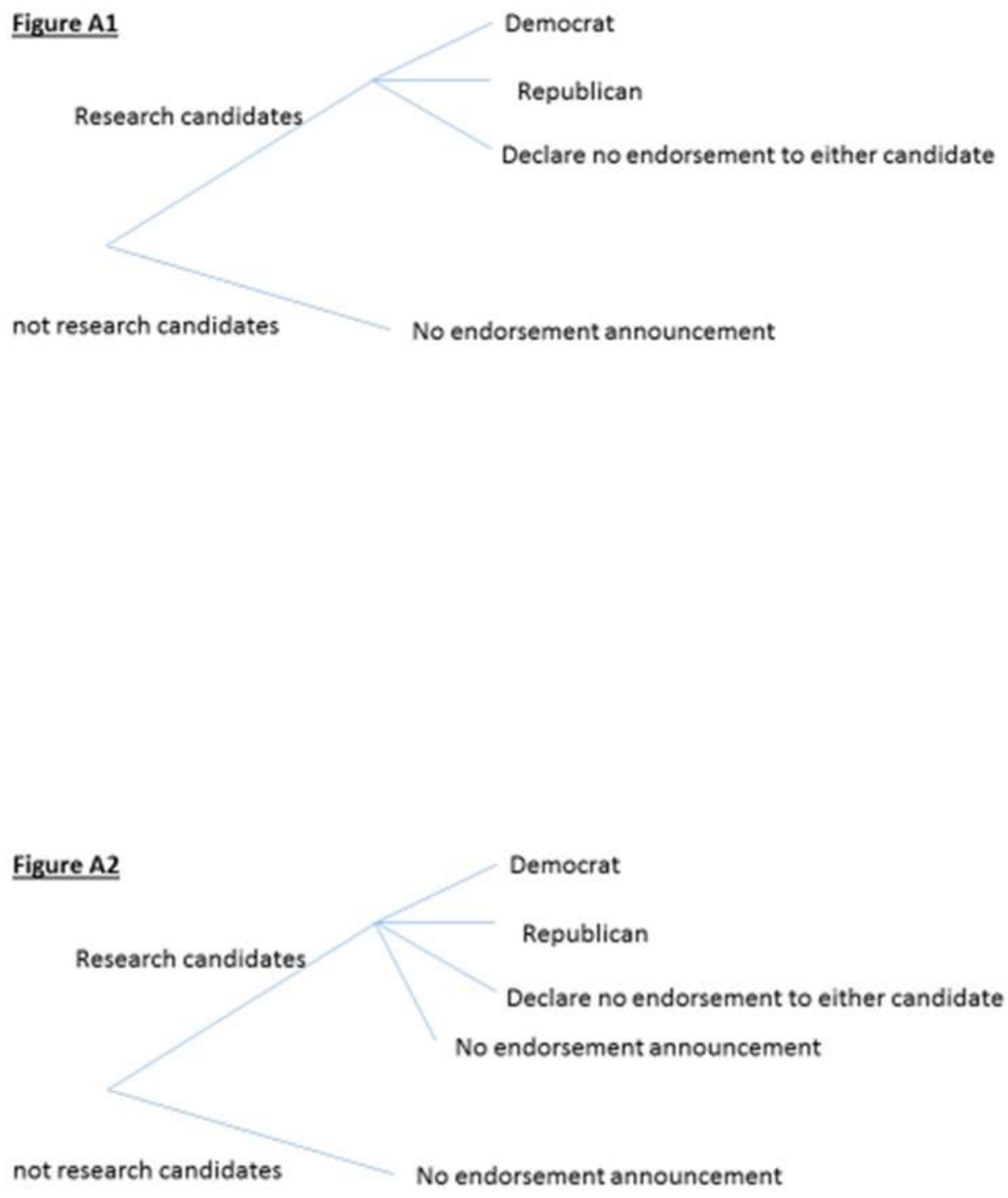


\section{Description of Explanatory Variables}

First Decision variables Description

Bo*Statewide

ßo*Open Race

Bo*Newspaper readers'share

Bo*Top 100 Newspaper

\section{$\underline{\mathrm{RCD}}$}

ßo*Urban

Bo*Population

Bo*Income

ßo*Political Homogeneity Index

$\beta 0^{*}$ College

Bo*White

ßo*Black

ßo*Hispanic

ßo*Male

$\underline{\mathrm{RCM}}$
Dummy of value one for the Endorsement alternative, and zero otherwise.

Dummy of value one for the Endorsement alternative in statewide races, and zero otherwise.

Dummy of value one for the Endorsement alternative in elections the incumbent is not running for re-election, and zero otherwise.

Dummy of value one for the Endorsement alternative times the newspaper readers' share in the jurisdiction, and zero otherwise.

Dummy of value one for the Endorsement alternative if the newspaper is among the largest 100 newspapers in the US.

Dummy of value one for the Endorsement alternative in jurisdictions where at least $47.9 \%$ of the newspaper readership lives in urban areas, and zero otherwise.

Dummy of value one for the Endorsement alternative in jurisdictions if newspaper readership lives in areas with, at least 153,164 habitants, and zero otherwise.

Dummy of value one for the Endorsement alternative in jurisdictions where the newspaper readership average income is at least

U 51,534 and zero otherwise.

Dummy of value one for the Endorsement alternative times political homogeneity index.

Dummy of value one for the Endorsement alternative in jurisdictions where at least $16.7 \%$ of newspaper readership has a college degree, and zero otherwise.

Dummy of value one for the Endorsement alternative in jurisdictions where at least $76.7 \%$ of the newspaper readership is white, and zero otherwise.

Dummy of value one for the Endorsement alternative in jurisdictions where at least $5.34 \%$ of the newspaper readership is

black, and zero otherwise.

Dummy of value one for the Endorsement alternative in jurisdictions where at least $14.61 \%$ of the newspaper readership is

hispanic, and zero otherwise.

Dummy of value one for the Endorsement alternative in jurisdictions where at least $50.03 \%$ of the newspaper readership is

male, and zero otherwise.

Dummy of value one for the Endorsement alternative* fraction of the jurisdiction where the newspaper operates as a monopolist. 
List of Elections by State and Year

\begin{tabular}{|c|c|c|c|}
\hline \multicolumn{2}{|c|}{ California } & \multicolumn{2}{|c|}{ Florida } \\
\hline 2002 & 2006 & 2002 & 2006 \\
\hline $\begin{array}{l}\text { Gubernatorial } \\
\text { State Attorney } \\
\text { Secretary of State } \\
\text { US House - district } 1 \\
\text { US House - district } 6 \\
\text { US House - district } 8 \\
\text { US House - district } 9 \\
\text { US House - district } 11 \\
\text { US House - district } 12 \\
\text { US House - district } 17 \\
\text { US House - district } 18 \\
\text { US House - district } 23 \\
\text { US House - district } 24 \\
\text { US House - district } 26\end{array}$ & $\begin{array}{l}\text { Gubernatorial } \\
\text { State Attorney } \\
\text { US Senate } \\
\text { US House - district } 1 \\
\text { US House - district } 2 \\
\text { US House - district } 3 \\
\text { US House - district } 4 \\
\text { US House - district } 5 \\
\text { US House - district } 6 \\
\text { US House - district } 7 \\
\text { US House - district } 8 \\
\text { US House - district } 9\end{array}$ & $\begin{array}{l}\text { Gubernatorial } \\
\text { State Attorney } \\
\text { US House - district } 5 \\
\text { US House - district } 6 \\
\text { US House - district } 7 \\
\text { US House - district } 9 \\
\text { US House - district } 13 \\
\text { US House - district } 15\end{array}$ & $\begin{array}{l}\text { Gubernatorial } \\
\text { State Attorney } \\
\text { US Senate } \\
\text { US House - district } 1 \\
\text { US House - district } 4 \\
\text { US House - district } 5 \\
\text { US House - district } 6 \\
\text { State Senate - district } 10 \\
\text { State Senate - district } 12 \\
\text { State Senate - district } 16 \\
\text { State Senate - district } 28\end{array}$ \\
\hline \multicolumn{2}{|c|}{ Michigan } & \multicolumn{2}{|c|}{ Ohio } \\
\hline 2002 & 2006 & 2002 & 2006 \\
\hline $\begin{array}{l}\text { Gubernatorial } \\
\text { State Attorney } \\
\text { US Senate } \\
\text { US House - district } 1 \\
\text { US House - district } 2 \\
\text { US House - district } 3 \\
\text { US House - district } 4 \\
\text { US House - district } 6 \\
\text { US House - district } 7 \\
\text { US House - district } 9 \\
\text { US House - district } 10 \\
\text { US House - district } 11 \\
\text { US House - district } 12 \\
\text { US House - district } 14\end{array}$ & $\begin{array}{l}\text { Gubernatorial } \\
\text { State Attorney } \\
\text { US Senate } \\
\text { US House - district } 1 \\
\text { US House - district } 2 \\
\text { US House - district } 3 \\
\text { US House - district } 4 \\
\text { US House - district } 5 \\
\text { US House - district } 6 \\
\text { US House - district } 7 \\
\text { US House - district } 8\end{array}$ & $\begin{array}{l}\text { Gubernatorial } \\
\text { State Attorney } \\
\text { Secretary of State } \\
\text { US House - district } 4 \\
\text { US House - district } 5 \\
\text { US House - district } 6 \\
\text { US House - district } 7 \\
\text { US House - district } 9 \\
\text { US House - district } 10 \\
\text { US House - district } 11 \\
\text { US House - district } 13 \\
\text { US House - district } 14 \\
\text { US House - district } 15 \\
\text { US House - district } 17\end{array}$ & $\begin{array}{l}\text { Gubernatorial } \\
\text { State Attorney } \\
\text { US Senate } \\
\text { US House - district } 1 \\
\text { US House - district } 2 \\
\text { US House - district } 3 \\
\text { US House - district } 4 \\
\text { US House - district } 5 \\
\text { US House - district } 6 \\
\text { US House - district } 7 \\
\text { US House - district } 8\end{array}$ \\
\hline \multicolumn{2}{|c|}{ Oregon } & \multicolumn{2}{|c|}{ Texas } \\
\hline 2002 & 2006 & 2002 & 2006 \\
\hline $\begin{array}{l}\text { Gubernatorial } \\
\text { US House - district } 1 \\
\text { US House - district } 4 \\
\text { US House - district } 5 \\
\text { US House - district } 6 \\
\text { State Senate - district } 4 \\
\text { State Senate - district } 7 \\
\text { State Senate - district } 13 \\
\text { State Senate - district } 15 \\
\text { State Senate - district } 17 \\
\text { State Senate - district } 19 \\
\text { State Senate - district } 26\end{array}$ & $\begin{array}{l}\text { Gubernatorial } \\
\text { US House - district } 1 \\
\text { US House - district } 4 \\
\text { US House - district } 5 \\
\text { US House - district } 6 \\
\text { State Senate - district } 3 \\
\text { State Senate - district } 4 \\
\text { State Senate - district } 6 \\
\text { State Senate - district } 7 \\
\text { State Senate - district } 10\end{array}$ & $\begin{array}{l}\text { Gubernatorial } \\
\text { State Attorney } \\
\text { US House - district } 3 \\
\text { US House - district } 4 \\
\text { US House - district } 5 \\
\text { US House - district } 6 \\
\text { US House - district } 13 \\
\text { US House - district } 24\end{array}$ & $\begin{array}{l}\text { Gubernatorial } \\
\text { State Attorney } \\
\text { US Senate } \\
\text { US House - district } 1 \\
\text { US House - district } 2 \\
\text { US House - district } 3 \\
\text { US House - district } 4 \\
\text { US House - district } 5 \\
\text { US House - district } 6 \\
\text { US House - district } 7 \\
\text { US House - district } 8\end{array}$ \\
\hline
\end{tabular}

Wisconsin

\begin{tabular}{|ll|}
\hline \multicolumn{1}{|c|}{2002} & \multicolumn{1}{c|}{ 2006 } \\
\hline Gubernatorial & Gubernatorial \\
State Attorney & State Attorney \\
US Senate & US Senate \\
US House - district 1 & US House - district 1 \\
US House - district 2 & US House - district 2 \\
US House - district 3 & US House - district 3 \\
US House - district 7 & US House - district 4 \\
US House - district 8 & US House - district 5 \\
& US House - district 6 \\
& US House - district 7 \\
& US House - district 8 \\
\hline
\end{tabular}

